\title{
EVALUATION OF DIETHERS AS URANIUM EXTRACTANTS
}

\author{
J. M. Googin \\ W. L. Harper \\ L. R. Phillips \\ F. W. Postma
}

\section{UNION CAREIDE NUCLEAR COMPANY DIVISION OF UNION CARBIDE CORPORATION \\ Operating \\ - oAk RIDge gaseous diffusion plant - oAK RIDGe y-12 pLant \\ - oak ridgenational laboratory - paducahgaseous diffusion plant \\ for the Atomic Energy Commission}

Under U. S. Government Contract W7405 eng 26 
Printed in USA. Price: $\$ 0.75$ Available from the

Office of Technical Services

U. S. Department of Commerce

Washington 25, D. C.

LEGAL NOTICE

This report was prepared as an account of Government sponsored work. Neither the United States, nor the Commission, nor any person acting on behalf of the Commission:

A. Makes any warranty or representation, expressed or implied, with respect to the accuracy, completeness, or usefulness of the information contained in this report, or that the use of any information, apparatus, method, or process disclosed in this report may not infringe privately owned rights; or

B. Assumes any liabilities with respect to the use of, or for damages resulting from the use of any information, apparatus, method, or process disclosed in this report.

As used in the above, "person acting on behalf of the Commission" includes any employee or contractor of the Commission, or employee of such contractor, to the extent that such employee or contractor of the Commission, or employee of such contractor prepares, disseminates, or provides access to, any information pursuant to his employment or contract with the Commission, or his employment with such contractor. 
Date Issued: January 14, 1963

Report Number Y-1408

Chemistry

TID-4500 (18th Edition)

UNION CARBIDE NUCLEAR COMPANY

Division of Union Carbide Corporation

$$
\text { Y-12 PLANT }
$$

Contract W-7405-eng-26

With the U. S. Atomic Energy Commission

EVALUATION OF DIETHERS AS URANIUM EXTRACTANTS

J. M. Googin

W. L. Harper

L. R. Phillips

F. W. Postma

Oak Ridge, Tennessee

October 2, 1962 
Report Number $Y-1408$

Chemistry

TID-4500 (18th Edition)

Distribution:

Ballenger, H. F.

Dow, Neal

Googin, J. M.

Harper, W. L.

Harwell, W. L.

(ORGDP)

(5)

Hemphill, L. F.

Jasny, G. R.

Keller, C. A.

(AEC-ORO)

(4)

Kite, H. T.

Lang, D. M.

(ORGDP)

Lewis, F. O.

(ORGDP)

Mitchel, G. W.

Murray, J.P.

(ORGDP)
Pfeiler, W. A.

Phillips, L. R.

Postma, F. W.

Rader, D. H.

Reece, J.S.

Schwenn, M. F.

Tench, F. M.

Waters, J. L.

Whitson, W. K., Jr.

Williams, R. D.

Winkel, R. A.

(Paducah)

Y-12 Central Files

$\mathrm{Y}-12$ Central Files $(\mathrm{Y}-12 \mathrm{RC})$

Patton, F. S.

In addition, this report is distributed in accordance with the category, Chemistry as given in the "USAEC Standard Distribution Lists for Unclassified Scientific and Technical Reports", TID-4500 (18th Edition), August 31, 1962. 
ABSTRACT

Some pertinent physical properties were determined for thirtytwo diethers and related compounds whose structures indicated that they might be good uranium extractants. Correlation of these properties with structures indicates that the use of the carbon-to-oxygen atomic ratio as a guide to the extraction power of an ether cannot be extended beyond a particular homologous series nor used when the spacing of the oxygen atoms in the ether is changed. The dipole moment appears to be a factor in explaining the differences in the extraction power of compounds with the same carbon-to-oxygen ratio.

The lower-membered dialkoxypentanes showed suitable physical properties and adequate uranium extraction capabilities. These were examined more thoroughly with respect to their use as uranium extractants in large-scale recovery operations. 


\section{CONTENTS}

INTRODUCTION ..................... 5

SUMMARY.......................... 6

EXPERIMENTAL WORK ..................... 7

Testing Procedures .................... . . 7

Some Physical Properties of a Number of Diethers and Related Compounds 7

Evaluation of the Dialkoxypentanes as Uranium Extractants. . . . . . 11

Evaluation of 1,5-Dimethoxypentane as a Uranium Extractant . . . . . 12

Distribution of Nitric Acid Between 1,5-Dimethoxypentane and Aluminum

Nitrate Solutions . . . . . . . . . . . . . . . 12

Effect of Aluminum Nitrate Concentration on the Uranium Distribution

Coefficient at a Constant Acid Concentration. . . . . . . . . 13

Effect of Nitric Acid on the Uranium Distribution Coefficient at

Several Aluminum Nitrate Concentrations . . . . . . . . 13

Effect of Nitric Acid on the Uranium Distribution Coefficient at a

Constant Nitrate Ion Concentration . . . . . . . . . . 15

Distribution of Uranium Between Nitric Acid and 1,5-Dimethoxypentane. . 16

Uranium Capacity ..................... . 17

Uranium Extraction Experiments With the Other Ethers. . . . . . . 17

Phase Separation Time .. . . . . . . . . . . . 18

Extractability of Impurities . . . . . . . . . . . . 18

Extraction of Zirconium. . . . . . . . . . . . . . . . . . 20

Separation of Uranium and Thorium . . . . . . . . . . . . . 22

Solubility of the Ethers in Aqueous Solution . . . . . . . . . 22

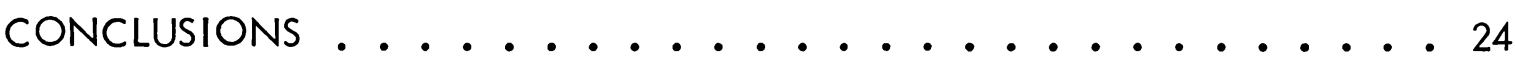

REFERENCES . . . . . . . . . . . . . . . . . 25

APPENDIX (METHODS OF DETERMINING PHYSICAL PROPERTIES) • • • • 27

Specific Property . . . . . . . . . . . . . . . . 27

Boiling Points . . . . . . . . . . . . . . . 27

Viscosities . . . . . . . . . . . . . . . . 27

Refractive Index . . . . . . . . . . . . . . . 27

Interfacial Tensions . . . . . . . . . . . . . . 27

Densities . . . . . . . . . . . . . . . . 27

Distribution Coefficients . . . . . . . . . . . . . 27

Dipole Moments . . . . . . . . . . . . . . 28 


\section{INTRODUCTION}

Dibutyl Carbitol, long used in column extractions of uranium from nitric acidsolutions in the $\mathrm{Y}-12$ Plant, has several distinct disadvantages: (1) it reacts with nitric acid, sometimes vigorously; (2) because of its high viscosity, it is slow in coalescing after dispersion, giving a low volume rate at column flooding; (3) it has a relatively high solubility in aqueous acid solutions; and (4) because of the ethylene glycol linkage in the ether, one of its chief oxidative degradation products is oxalic acid which reacts with the uranyl ion and precipitates in the system the sparsely soluble uranyl oxalate.

These deficiencies in dibutyl Carbitol as a uranium extractant led to a search for a superior solvent. A number of other ethers and related compounds were suggested because of their promising molecular structures, for measurement of their physical properties and extraction capabilities. 


\section{SUMMARY}

In a search for a solvent superior to dibutyl Carbitol for uranium extraction from nitric acid solution, several physical properties, pertinent to uranium extraction, were determined for a number of ethers and related compounds. 1,5-dimethoxypentane, 1,5-diethoxypentane, and 1-methoxy-5-ethoxypentane, were evaluated as uranium extractants and compared with dibutyl and hexyl ethyl Carbitol in a uranyl nitrate-aluminum nitrate-nitric acid-water system.

Results of the investigations have indicated the following:

1. The extraction power of an ether is some function of its carbon-to-oxygen ratio and its dipole moment.

2. The three dialkoxypentanes have physical properties which are, generally speaking, superior to dibutyl Carbitol and have adequate extraction capacity for uranium; however, the use of 1,5-dimethoxypentane in continuous column extraction is severely limited by its high solubility in aqueous solutions.

3. Of the three ethers, 1,5-dimethoxypentane has the highest uranium distribution coefficient, 1,5-diethoxypentane the lowest, and the mixed ether between the two symmetrical ethers.

4. The uranium distribution coefficients decrease with increasing free-acid concentration and increase with increasing aluminum nitrate concentration.

5. Adequate purification of the uranium is obtained when extracted from impure solutions by any of the three dialkoxypentanes. 


\section{EXPERIMENTAL WORK}

\section{TESTING PROCEDURES}

Some Physical Properties of a Number of Diethers and Related Compounds

Introduction - Some pertinent physical properties were determined for thirty-two diethers and related compounds whose structures indicated that they might be good uranium extractants. Boiling points, viscosities, refractive indices, some dipole moments, interfacial tensions, densities, and uranium distribution coefficients were determined and compared with similar data for dibutyl Carbitol. These physical properties together with skeletal structural formulas are presented in Table 1. The methods of determining the various properties are given in the Appendix.

Those compounds which were not readily available commercially were prepared in the laboratory, principally by conventional methods such as the Williamson Synthesis.

During the determination of the distribution coefficients, volume changes in the two phases were noted and recorded. This procedure provided a rough estimation of the solubility of the two phases in each other. The last two columns of Table 1 present this information.

Some tentative conclusions can be formulated from the data presented in Table 1.

Carbon-to-Oxygen Ratio Within an Homologous Series - It has been reported that the extraction power of an ether is some function of the ratio of the number of carbon atoms in the molecule to the number of oxygen atoms. (1) Thus, among members of an homologous series of ethers an increasing number of carbons and a constant number of oxygens (an increase in $c / 0$ ), would produce a rapid decrease in the extraction power of the solvents. The data for the dialkoxybutane and dialkoxypentane homologous series, shown in Table 1, have been plotted in Figure 1 to illustrate this relationship. The numbers adjacent to each datum point in Figure 1 refer to the number of carbon atoms in one terminal group, the number in the center group, and the number in the other terminal group, respectively. These results have been confirmed by the work of Burger. (2)

Carbon-to-Oxygen Ratio Beyond a Homologous Series - The data in Table 1 also show that the comparison of extractabilities on the basis of the carbon-to-oxygen ratio cannot be extended beyond a particular homologous series. For example, 2methyltetrahydrapyran is a much better extractant than is diethyl ether, even though the carbon-to-oxygen ratio is much more favorable for the latter. 
Table 1

SOME PHYSICAL CONSTANTS OF ETHERS AND RELATED COMPOUNDS

\begin{tabular}{|c|c|c|c|c|c|c|c|c|c|c|c|c|c|c|}
\hline \multirow{2}{*}{ Ether } & \multirow[b]{2}{*}{$\begin{array}{r}\text { Structure } \\
\text { (skeletal) }\end{array}$} & \multirow{2}{*}{$\begin{array}{c}\text { Carbon: } \\
\text { Oxysen } \\
\text { Ratio } \\
\end{array}$} & \multirow[b]{2}{*}{ B. PT. ${ }^{\circ} \mathrm{C}$} & \multirow{2}{*}{$\begin{array}{c}\text { Absolute } \\
\text { Viscosity } \\
\text { ot } 25^{\circ} \mathrm{C} \\
\text { (centipoise) }\end{array}$} & \multirow{2}{*}{$\begin{array}{l}\text { Refractive } \\
\text { Index ot } \\
25^{\circ} \mathrm{C} \\
\left(\mathrm{n}_{\mathrm{D}}\right)\end{array}$} & \multirow{2}{*}{$\begin{array}{l}\text { Interfacial } \\
\text { Tension vs } \mathrm{H}_{2} \mathrm{O} \\
\text { of } 25^{\circ} \mathrm{C} \\
\text { (dynos/cm) }\end{array}$} & \multirow{2}{*}{ 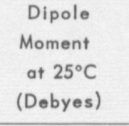 } & \multirow{2}{*}{$\begin{array}{l}\text { Density } \\
\text { ot } 25{ }^{5} \mathrm{C} \\
(\mathrm{g} / \mathrm{ml})\end{array}$} & \multirow{2}{*}{\multicolumn{2}{|c|}{$\begin{array}{l}\text { Uranium Distribution } \\
\text { Coofficient } \\
E_{a}^{\circ} \\
\end{array}$}} & \multicolumn{4}{|c|}{$\begin{array}{l}\text { Phase Volume at Equillibrium (\%) } \\
\mathrm{NH}_{4} \mathrm{NO}_{3} \text { 筑 } \mathrm{O}\end{array}$} \\
\hline & & & & & & & & & & & $\frac{\mathrm{NH}_{4}}{\mathrm{Aq}_{9}}$ & & $\frac{\mathrm{H}_{2}}{\mathrm{Aq}}$ & \\
\hline bis (2-butoxyothyl) ether (dibytyl Carbitol) & c.c-c.c-c.o-c.c-o.c.c-o.c-c.c-c & 4.0 & 254.6 & 2.04 & 1.4208 & 12.65 & $1.83 \pm 0.06$ & 0.8797 & 3.8 & 0.29 & 90 & 105 & 95 & 100 \\
\hline diethyleneglycol di-tertbutyl ether (ditertiary-butyl Carbitol) & C-ç-o-c-c-o-c-c-o-c-c-c & 4.0 & & 2.67 & 1.4168 & 8.43 & .. & 0.8716 & 17.37 & 1.28 & 95 & 103 & 100 & 98 \\
\hline $\begin{array}{l}\text { ethoxyethylene-1-ethylenedioxyhexane (hexyl ethyl Carbitol) } \\
\text { 1-methoxy-2-butoxyethane (methyl buty| Cellosolve) }\end{array}$ & $\begin{array}{l}\text { c-c.-o-c.c-o-c.c-o.c-c-c.c-c.c-c } \\
\text { c-c.c-c.-o-c.c-o.c }\end{array}$ & $\begin{array}{l}4.0 \\
3.5\end{array}$ & $146-7$ & $\begin{array}{l}2.10 \\
0.771\end{array}$ & $\begin{array}{l}1.4320 \\
1.3996\end{array}$ & $\begin{array}{l}8.43 \\
7.84\end{array}$ & $\begin{array}{c}2.02 \pm 0.15 \\
-.\end{array}$ & $\begin{array}{l}0.8815 \\
0.8443\end{array}$ & $\begin{array}{l}6.96 \\
3.1\end{array}$ & $\begin{array}{l}0.66 \\
0.37\end{array}$ & $\begin{array}{l}93 \\
95\end{array}$ & $\begin{array}{l}110 \\
105\end{array}$ & 97 & $\begin{array}{r}105 \\
95\end{array}$ \\
\hline 1-methoxy-2-(2-methylpropoxy) ethane (methyl iso-butyl cellosolve) & c-ç-c-o-c-c-o-c & 3.5 & $136-8$ & 0.724 & 1.3962 & 8.93 & -. & 0.8324 & 1.6 & 0.18 & 95 & 95 & 100 & 95 \\
\hline 1-ethoxy-2-butoxyethone (ethyl butyl Cellosolve) & c-c.c-c-o-c-c-o-c-c & 4.0 & 164.2 & 0.861 & 1.4022 & 12.85 & $\therefore$ & 0.8326 & 1.3 & 0.14 & 85 & 95 & 90 & 95 \\
\hline $\begin{array}{l}\text { 1-methoxy-2-pentaxyethane (methy| n-amy| Cellosolve) } \\
\text { 1-methoxy-2-eyclohexoxyethone (methy| cyclohexy| Cellosolve) }\end{array}$ & $\begin{array}{l}\text { C-C-C-C-C-O-C-C-O-C } \\
\mathrm{C}_{6} \mathrm{H}_{11}-\mathrm{O}-\mathrm{C}-\mathrm{C}-\mathrm{O}-\mathrm{C}\end{array}$ & $\begin{array}{l}4.0 \\
4.5\end{array}$ & $\begin{array}{l}164-8 \\
192-6\end{array}$ & 0.902 & $\begin{array}{l}1.4054 \\
1.4412\end{array}$ & $\begin{array}{r}10.23 \\
5.74\end{array}$ & $\begin{array}{c}1.73 \pm 0.22 \\
-.\end{array}$ & $\begin{array}{l}0.8415 \\
0.9365\end{array}$ & $\begin{array}{l}1.7 \\
5.1\end{array}$ & $\begin{array}{l}0.19 \\
0.49\end{array}$ & $\begin{array}{l}95 \\
95\end{array}$ & $\begin{array}{r}95 \\
105\end{array}$ & $\begin{array}{l}90 \\
90\end{array}$ & $\begin{array}{l}95 \\
95\end{array}$ \\
\hline 1-methoxy-2-ethoxypropane & $c-c-0-c^{-c-c-o-c}$ & 3.0 & 109 & 0.630 & 1.3900 & 4.17 & -. & 0.8493 & 5.5 & 0.70 & 95 & 95 & 155 & 35 \\
\hline 1-methoxy-3-butoxypropane & c-c-c-c-o-c-c-c-o-c & 4.0 & $164-7$ & 0.940 & 1.4052 & 9.59 & -. & 0.8402 & 1.2 & 0.15 & 90 & 100 & 100 & 95 \\
\hline 1-propoxy-2-methoxypropane & c.c-c.o-c-ç-o.c & 3.5 & $133-6$ & 0.670 & 1.3952 & 7.72 & -. & 0.8358 & 2.0 & 0.24 & 90 & 105 & 105 & 90 \\
\hline 1-(1-methylethoxy)-2-methoxypropane & c-ç-o-c-ç-o-c & 3.5 & $122-4$ & 0.617 & 1.3900 & 7.50 & -. & 0.8260 & 2.6 & 0.30 & 90 & 105 & 110 & 85 \\
\hline 1,4-dimethoxybutane & 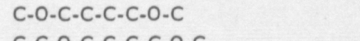 & 3.0 & $132-4$ & 0.697 & 1.3990 & $\ddot{0}$ & -. & 0.8639 & 7.9 & 1.1 & 90 & 110 & 150 & 50 \\
\hline $\begin{array}{l}\text { 1-methoxy-4-ethoxybutane } \\
\text { 1,4-diethoxybutane }\end{array}$ & $\begin{array}{l}\text { c-c-o-c-c-c-c-o-c } \\
\text { c-c-o-c-c-c-c-o-c-c }\end{array}$ & $\begin{array}{l}3.5 \\
4.0\end{array}$ & $\begin{array}{l}150 \\
163-5\end{array}$ & 0.815 & $\begin{array}{l}1.4014 \\
1.4042\end{array}$ & $\begin{array}{r}6.12 \\
10.20\end{array}$ & $\ddot{-}$ & $\begin{array}{l}0.8433 \\
0.8354\end{array}$ & $\begin{array}{l}6.0 \\
1.9\end{array}$ & $\begin{array}{l}0.76 \\
0.27\end{array}$ & $\begin{array}{l}90 \\
90\end{array}$ & $\begin{array}{l}105 \\
105\end{array}$ & $\begin{array}{r}115 \\
90\end{array}$ & $\begin{array}{l}85 \\
95\end{array}$ \\
\hline 1-ethoxy-3-methoxybutone & c-c-o-c-c-c-o.c & 3.5 & $136-8$ & 0.679 & 1.3986 & 7.20 & -. & 0.8358 & 2.9 & 0.38 & 90 & 100 & 110 & 85 \\
\hline 1,5-dimethoxypentane & c-o-c-c-c-c-c-o-c & 3.5 & $154-6$ & 0.858 & 1.4092 & 5.90 & $1.79 \pm 0.12$ & 0.8897 & 8.4 & 1.1 & 85 & 105 & 110 & 75 \\
\hline $\begin{array}{l}\text { 1-methoxy-5-ethoxypentane } \\
\text { 1,5-5iethoxypentane }\end{array}$ & $\begin{array}{l}\text { c-o-c-c-c-c-c-o-c-c } \\
\text { c-c-o-c-c-c-c-c-o-c-c }\end{array}$ & $\begin{array}{l}4.0 \\
4.5\end{array}$ & $\begin{array}{l}172-3 \\
186-7\end{array}$ & $\begin{array}{l}1.10 \\
1.45\end{array}$ & $\begin{array}{l}1.4098 \\
1.4130\end{array}$ & $\begin{array}{l}6.47 \\
9.80\end{array}$ & $\begin{array}{l}1.83 \pm 0.06 \\
1.69 \pm 0.12\end{array}$ & $\begin{array}{l}0.8562 \\
0.8564\end{array}$ & $\begin{array}{l}4.9 \\
2.00\end{array}$ & $\begin{array}{l}0.48 \\
0.21\end{array}$ & 85 & 110 & ${ }^{111}$ & $\begin{array}{l}93 \\
\ldots\end{array}$ \\
\hline 1,6-dimethoxyhexane & c-o.c-c-c-c-c-c-o-c & 4.0 & $176-8$ & 1.03 & 1.4110 & 8.52 & -. & 0.8505 & 4.3 & 0.47 & 90 & 105 & 95 & 95 \\
\hline 1,2,6-triethoxyhexane & $\begin{array}{c}\text { c-c.o-c.c-c-c-c-c-c-o-c.c } \\
\text { o-c-c-c }\end{array}$ & 4.0 & 232-7 & 2.62 & 1.4223 & 8.81 & -. & 0.8839 & 1.8 & 0.28 & 90 & 105 & 95 & 90 \\
\hline 1,2-dimethoxycyclohexane & c-o-c-c-c-c-c-c-o-o-c & 4.0 & $\begin{array}{l}271 . \\
271.5\end{array}$ & 1.40 & 1.4398 & 3.18 & -. & 0.9473 & 9.5 & 1.2 & 90 & 100 & 110 & 85 \\
\hline tetrahydropyran & c-c.c-c.c & 5.0 & $85-77$ & 0.804 & 1.4175 & 6.25 & 1.87 ref..$^{(2)}$ & 0.8783 & 18.0 & 2.2 & 85 & 105 & 95 & 90 \\
\hline 2-methyl tetrahydropyran & {$\left[\begin{array}{cc}c-c-c-c-c-c \\
0-c\end{array}\right.$} & 6.0 & $105-10$ & 0.636 & 1.4158 & 12.07 & -- & 0.8326 & 6.6 & 0.96 & 90 & 105 & 90 & 90 \\
\hline 2-(ethoxymethyl) tefrahydropyran & {$\left[\begin{array}{c}c-c-c-c-c-c-c-o-c-c \\
0-c\end{array}\right.$} & 4.0 & $174-6$ & 1.85 & 1.4356 & 4.26 & -- & 0.9423 & 14.0 & 1.6 & 90 & 105 & 120 & 65 \\
\hline 2,5-dimethyl-1,4-dioxane & $\begin{array}{c}d-c \\
-c\end{array}$ & 3.0 & $113-5$ & 0.991 & 1.4064 & 7.06 & -. & 0.9381 & 1.1 & 0.20 & 100 & 90 & 135 & 65 \\
\hline 2,3,5,6-tetramethyl-1,4-dioxane & C-c-c-o-c-c-c-c-c & 4.0 & 145 & 1.27 & 1.4124 & 5.91 & -. & 0.9142 & 2.4 & 0.36 & 110 & 85 & 145 & 50 \\
\hline bis (3-methoxybutyl) ether & $\begin{array}{c}\text { c-o-c-c-c-o-c-c-c-c-o-c } \\
c\end{array}$ & 3.3 & $210-3$ & 1.54 & 1.4162 & 5.61 & -. & 0.8900 & 5.7 & 0.77 & 85 & 105 & 115 & 75 \\
\hline butoxy acetone & c-c-c.c-c-o-c-ç-c.c & 3.5 & $162-3$ & 1.93 & 1.4108 & 3.74 & -. & 0.8990 & 2.2 & 0.28 & 95 & 95 & 110 & 90 \\
\hline 2-pentanone & c-c-c-ç-c & 5.0 & 107.7 & 0.491 & 1.3877 & 6.49 & $2.71 \pm 0.20$ & 0.8016 & 4.9 & 0.49 & 95 & 105 & 105 & 95 \\
\hline methyl propionate & $\begin{array}{c}c-c-c-O-C \\
0\end{array}$ & 2.0 & $79-81$ & 0.476 & 1.3742 & 8.36 & $1.74 \pm 0.15$ & 0.9054 & 0.85 & 0.14 & 95 & 100 & 105 & 90 \\
\hline dimethyl adipate & $c-0 .-\bar{d}-c-c-c-c-c-c]-0-c$ & 2.0 & $\begin{array}{l}9-10 \\
\text { M.PT }\end{array}$ & 2.84 & 1.4260 & -. & $2.21 \pm 0.06$ & 1.046 & 1.6 & 0.26 & 97 & 103 & 102 & 98 \\
\hline
\end{tabular}




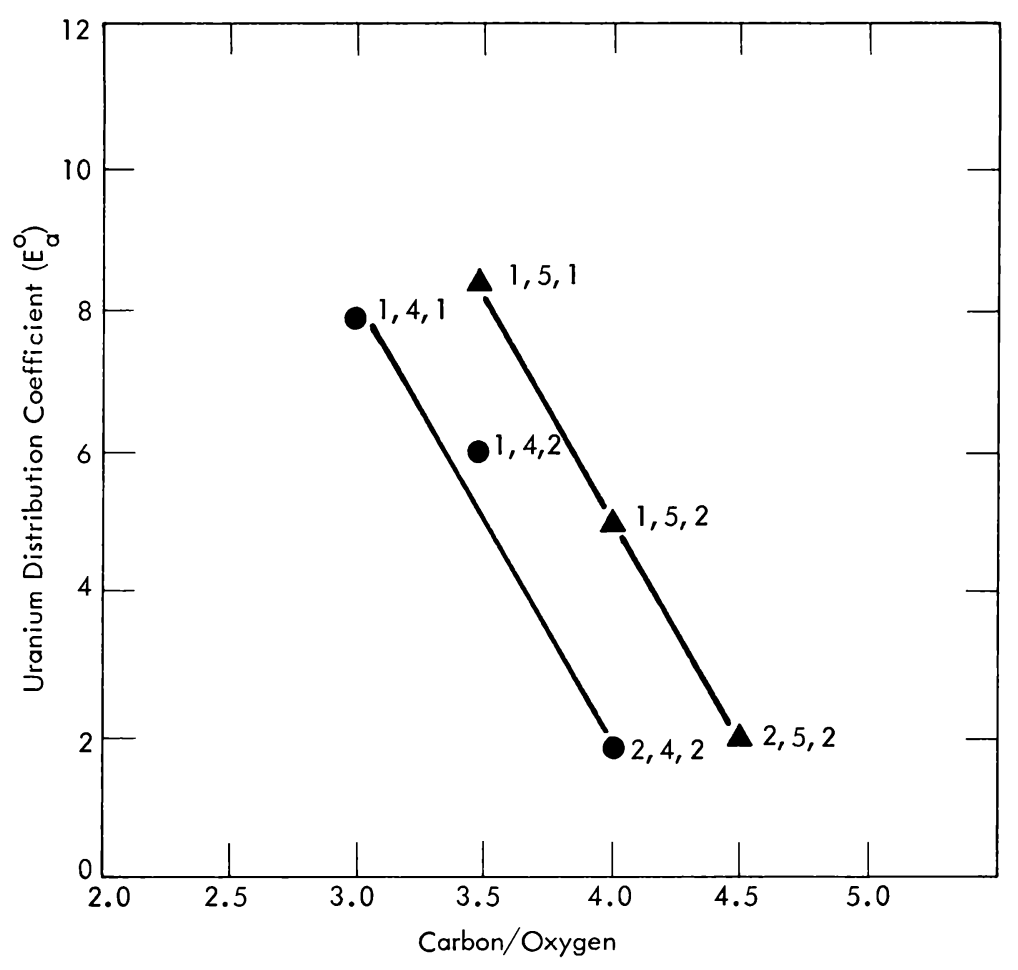

Figure 1. URANIUM DISTRIBUTION COEFFICIENTS OF DIALKOXY. BUTANES AND PENTANES AS FUNCTIONS OF THE CARBON-TO OXYGEN RATIO.

Influence of More Than One Ether Group - These data further indicate that when there is more than one ether group per molecule, the carbon-to-oxygen ratio can be used as a guide to the extraction power only when the spacing of the oxygen atoms in the molecule is unchanged in the series. Comparison of extractions by members of a family like $\mathrm{R}^{\prime} \mathrm{O}\left(\mathrm{CH}_{2}\right)_{2} \mathrm{OR}$ will reflect the carbon-to-oxygen ratio accurately; comparisons between this series and one like $\mathrm{R}^{\prime} \mathrm{O}\left(\mathrm{CH}_{2}\right)_{5} \mathrm{OR}$ will show little connection with the ratio.

Influence of Dipole Moment - The dipole moment appears to be one factor which is responsible for the differences found in the extraction power of compounds with the same carbon-to-oxygen ratio. The available data provides supporting evidence for this proposition to a limited degree.

Figure 2 shows the correlation of extraction power and dipole moment for four straight-chained diethers, three carbonyl compounds, and two straight-chained triethers. As the dipole moment increases, the extraction power increases. The slopes of the lines are undoubtedly influenced by the number, kind, and position of the functional groups present.

In addition to the data in Figure 2, it is interesting to note that the dipole moment of tetrahydropyran is relatively high ( 1.87 debyes), (3) and this compound has one of the highest extraction coefficients of all the compounds studied in spite of its $C: O$ 
ratio of 5. The dipole moments of 2,3,5,6-tetramethyl-1,4-dioxane and 2,5-dimethyl-1, 4-dioxane are expected to be low, since the dipole moment of 1,4-dioxane is only $0.4(4)$ debye, and it is a fact that neither of these compounds is a particularly good extraction agent although they have cyclic structures similar to tetrahydropyran and have more favorable carbon-to-oxygen ratios of 4 and 3 respectively.

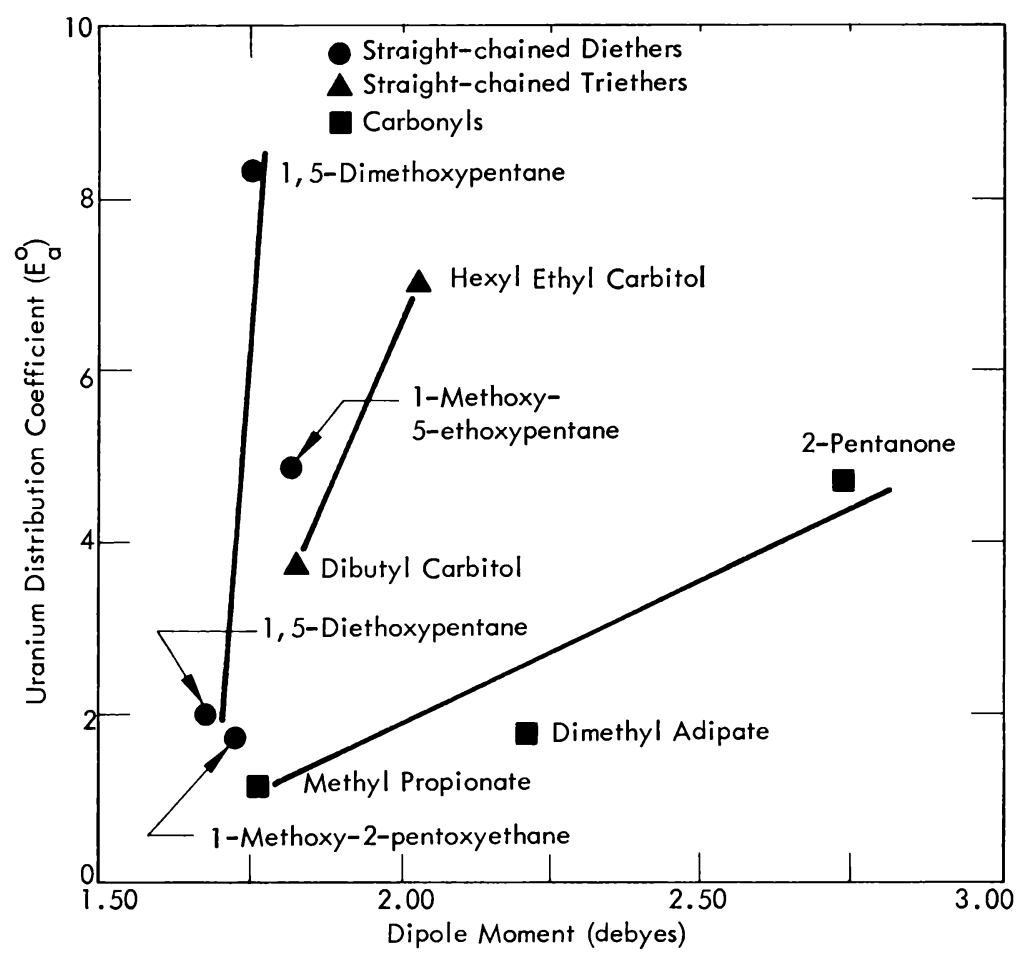

Figure 2. CORRELATION OF DIPOLE MOMENTS WITH EXTRACTION POWER.

Several of the compounds investigated have the empirical formulas $\mathrm{C}_{7} \mathrm{H}_{16} \mathrm{O}_{2}$ and $\mathrm{C}_{8} \mathrm{H}_{18} \mathrm{O}_{2}$. Among these compounds those with two methylene groups between the functional oxygens of the ether groups have been shown to be relatively poor extraction agents, while those with four to six methylene groups between the functional oxygens have extraction powers comparable to, or greater than, dibutyl Carbitol. This increase in extraction power with increasing spacing of the oxygen atoms in diethers is shown in Figure 3. The numbers adjacent to each datum point have the same connotation as those in Figure 1. Such trends have also been shown by Burger.(2) The increased extraction with greater separation of the "ether oxygen" atoms suggests that they act with increasing independence in the extraction of uranium as they are located farther apart in the molecule. It has been reported by Branch and Calvin(5) that the greater the separation of bromine atoms in alkyl dibromides the more independent are their contributions to the dipole moment. This is probably also true with the diethers, which would explain the trend of the data in Figure 3.

While some of the cyclic ethers have high uranium distribution coefficients, they exhibit only moderate resistance to nitric acid and were not considered further for 
industrial application; however, they are useful for laboratory scale work. Considerable work has been done in this field by Brancia. (6)

The dialkoxypentanes show moderately low viscosities and interfacial tensions, properties which should produce more rapid coalescence following dispersion, thus permitting high flooding flows in extraction equipment. The uranium distribution coefficients are adequately high, there being five methylene groups between the two ether oxygens.

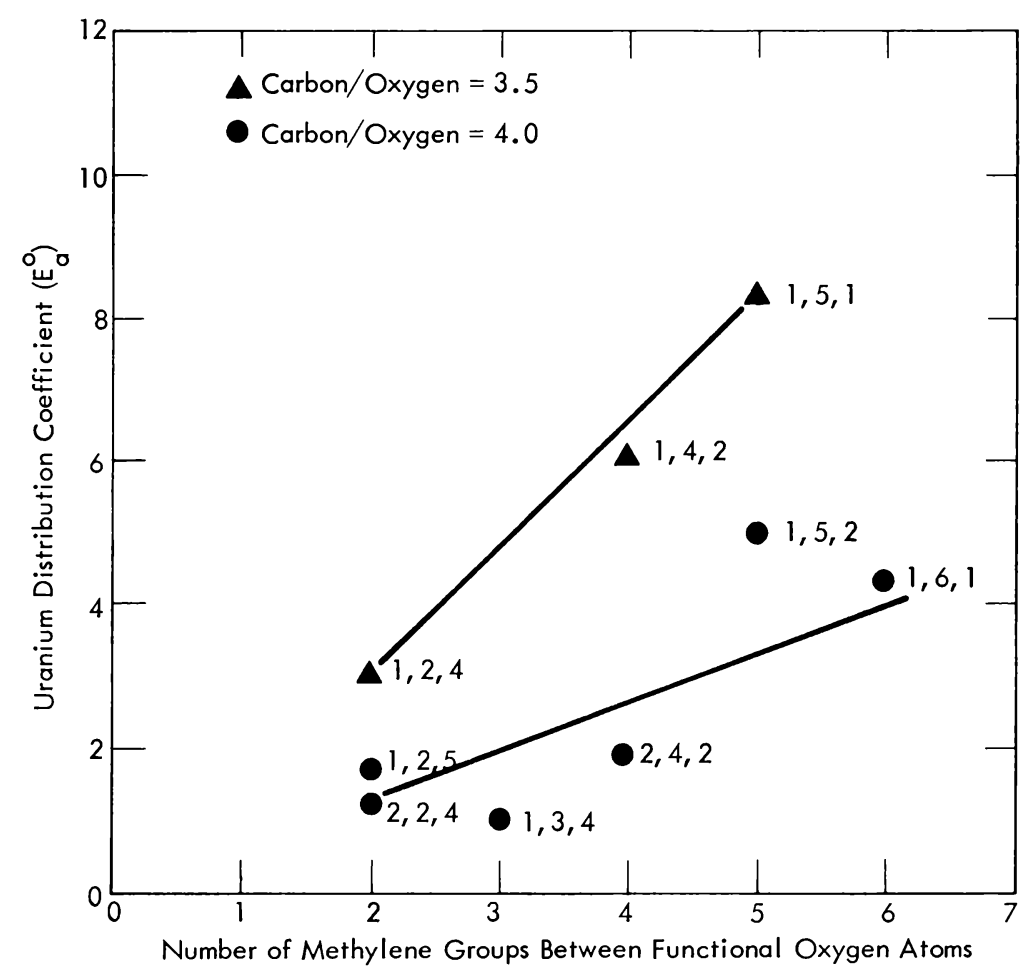

Figure 3. URANIUM DISTRIBUTION COEFFICIENT AS A FUNCTION OF THE O.O SPACING FOR SOME DIETHERS WITH EMPIRICAL FORMULAS OF $\mathrm{C}_{7} \mathrm{H}_{16} \mathrm{O}_{2}$ and $\mathrm{C}_{8} \mathrm{H}_{18} \mathrm{O}_{2}$.

Further, qualitative tests have shown a moderate solubility in acidsolution for uranyl glutarate, which would be produced as a result of oxidative degradation of the ether in a uranyl nitrate-nitric acid extraction system. This would be a decided advantage since appreciable problems are created in extraction column operations by the precipitation of uranyl oxalate as the result of the degradation of dibutyl Carbitol in nitric acid media. The combination of favorable properties made the dialkoxypentanes favorable candidates for further study.

Evaluation of the Dialkoxypentanes as Uranium Extractants

The three methyl and ethyl diethers of 1,5-pentanediol were obtained for further evaluation. Initially, they were prepared from 1,5-pentanediol by converting diol 
to tetrahydropyran, $(7)$ then severing the ring with the desired sodium alcoholates. (8) Later, adequate quantities of the 1,5-dimethoxypentane were furnished by Roberts Chemicals.

Because of its lower carbon-to-oxygen atomic ratio, 1,5-dimethoxypentane should be the best of these three ethers as a uranium extractant. Most of the extraction data were determined with this ether; however, a number of pertinent comparisons were made with the two otheralkoxypentanes. Similar comparative experiments were performed with hexyl ethyl Carbitol and dibutyl Carbitol.

Evaluation of 1,5-Dimethoxypentane as a Uranium Extractant

Uranium distribution coefficients for the system 1,5-dimethoxypentane-uranyl nitratealuminum nitrate-nitric acid-water were determined as functions of the free-acid and aluminum nitrate concentrations.

The feed solutions for extraction were prepared from $\mathrm{UO}_{2}\left(\mathrm{NO}_{3}\right)_{2} \cdot 6 \mathrm{H}_{2} \mathrm{O}$ crystals, $\mathrm{Al}\left(\mathrm{NO}_{3}\right)_{3} \cdot 9 \mathrm{H}_{2} \mathrm{O}$, and $70 \% \mathrm{HNO}_{3}$, all of chemically pure quality. Unless otherwise noted, all solutions were prepared to contain $10 \mathrm{~g} \mathrm{U} /$ liter, with varying amounts of the acid and salting agent.

The extractions consisted of two-minute hand shakeouts with equal volumes of the organic and aqueous phases in 125-milliliter separatory funnels. After separation of the phases, each was filtered through Whatman 42 filter paper to remove traces of the opposite phase. The uranium concentration in each phase was determined. Except in two instances, uranium material balances around the individual extractions were between 95 and 105 percent.

Acid concentrations were determined by dilution and titration. Samples of the feed, raffinate, and organic phases were volumetrically diluted with water in a ratio of one to twenty-five, then titrated with a standard $\mathrm{NaOH}$ solution to a $\mathrm{pH}$ of 3.0 as indicated by a glass electrode. Since chemically pure reagents were used, only nitric acid should be titrated at this $\mathrm{pH}$. Very low acidities were determined by calculation from the $\mathrm{pH}$ of the diluted sample.

Distribution of Nitric Acid Between 1,5-Dimethoxypentane and Aluminum Nitrate Solutions

Since it is known that variations in acid concentration can have considerable influence on the distribution of uranium, (9) it was necessary to determine the distribution of the nitric acid between the 1,5-dimethoxypentane and the aluminum nitrate solutions. Figure 4 shows the effect of the variation of the acid concentration on the extraction of nitric acid into the organic phase. A linear relationship in the acid distributions between the two phases appears to exist at the higher nitrate concentrations. The acid distribution coefficient (org/aq) increases with increasing acidity within the concentration limits of the experiments and rises rapidly with increasing nitrate 
concentration. A semilog plot of the acid distribution coefficient versus normality of the salt at a constant acid concentration is presented in Figure 5.

Effect of Aluminum Nitrate Concentration on the Uranium Distribution Coefficient at a Constant Acid Concentration

Data showing the effect of the aluminum nitrate concentration on the uranium distribution coefficient with 1,5-dimethoxypentane are presented in Figure 6. In these experiments a constant uranium feed concentration of $10 \mathrm{~g} /$ liter and very low nitric acid concentration (from hydrolysis of the salt only) were maintained. It can be seen that the uranium distribution coefficient $(\mathrm{org} / \mathrm{aq})$ rises very rapidly from 0.075 in $1.10 \mathrm{~N} \mathrm{Al}\left(\mathrm{NO}_{3}\right)_{3}$ to 402 in $7.08 \mathrm{~N} \mathrm{Al}\left(\mathrm{NO}_{3}\right)_{3}$, an effect to be expected in view of the "salting-out" property of aluminum nitrate.

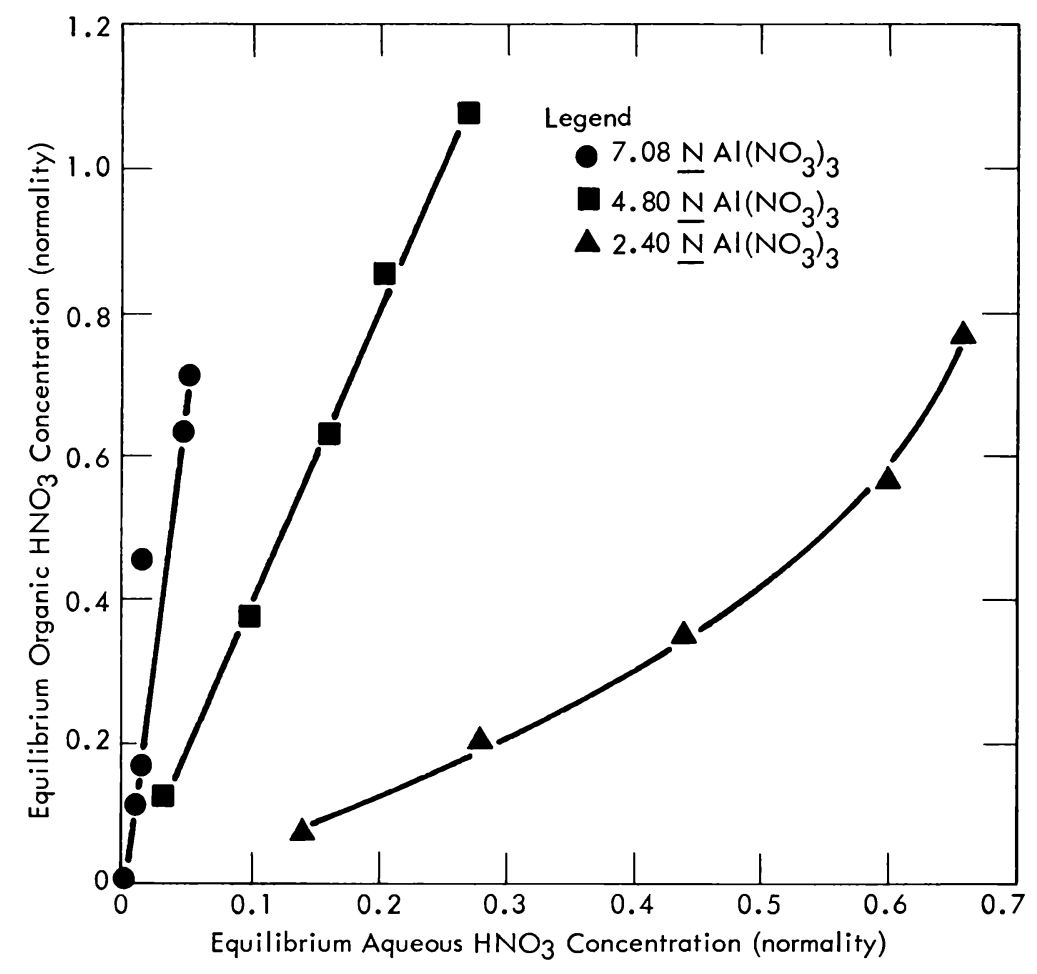

Figure 4. DISTRIBUTION OF NITRIC ACID BETWEEN 1,5-DIMETHOXYPENTANE AND ALUMINUM NITRATE.

Effect of Nitric Acid on the Uranium Distribution Coefficient at Several Aluminum Nitrate Concentrations

To determine the effect of nitric acid on the uranium distribution coefficient at various salt concentrations, extractions were made at three nitrate levels. Results are shown in Figure 7. The data obtained in the $5.1-6.7 \mathrm{~N} \mathrm{Al}\left(\mathrm{NO}_{3}\right)_{3}$ concentration range do not represent a true comparison with the other $\sqrt{a t a}$ because of the variation in the 


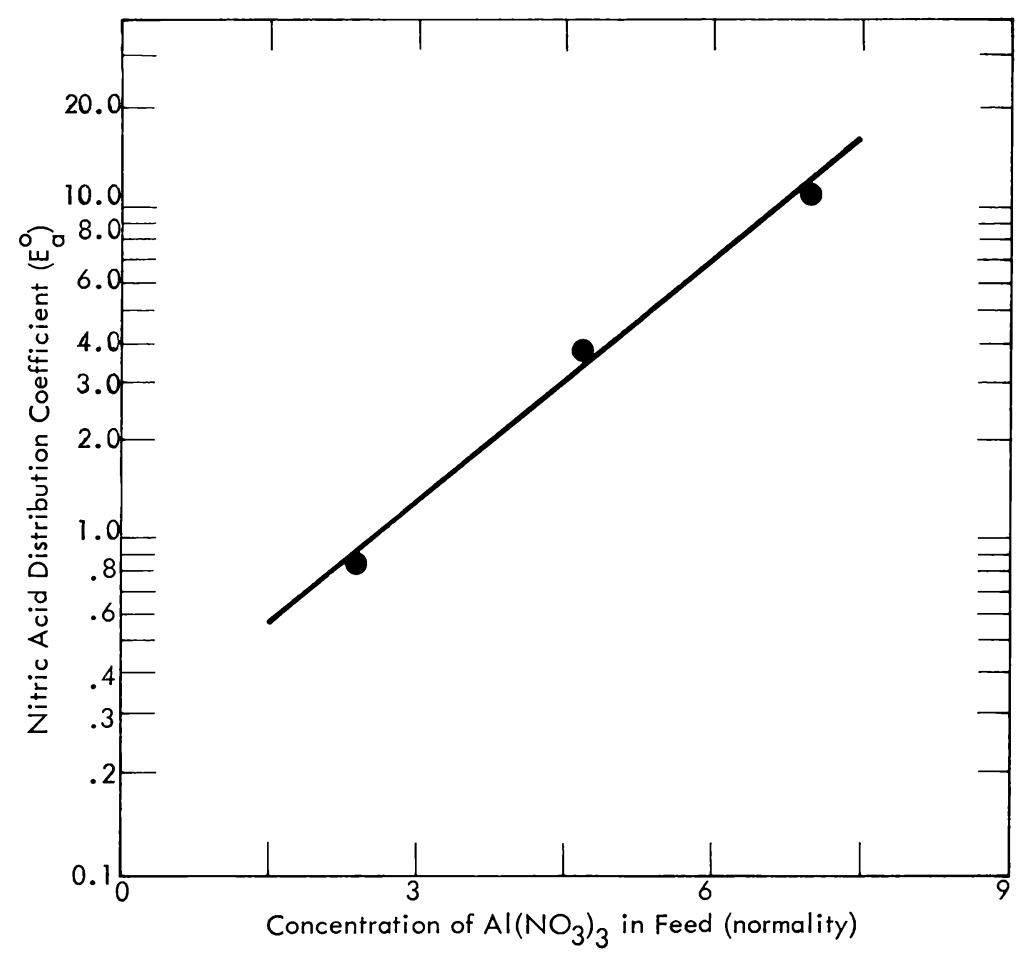

Figure 5. DISTRIBUTION OF NITRIC ACID BETWEEN 1,5-DIMETHOXYPENTANE AND ALUMINUM NITRATE. (At a Constant Acid Concentration of $0.4 \mathrm{~N}$ in the Organic Phase)

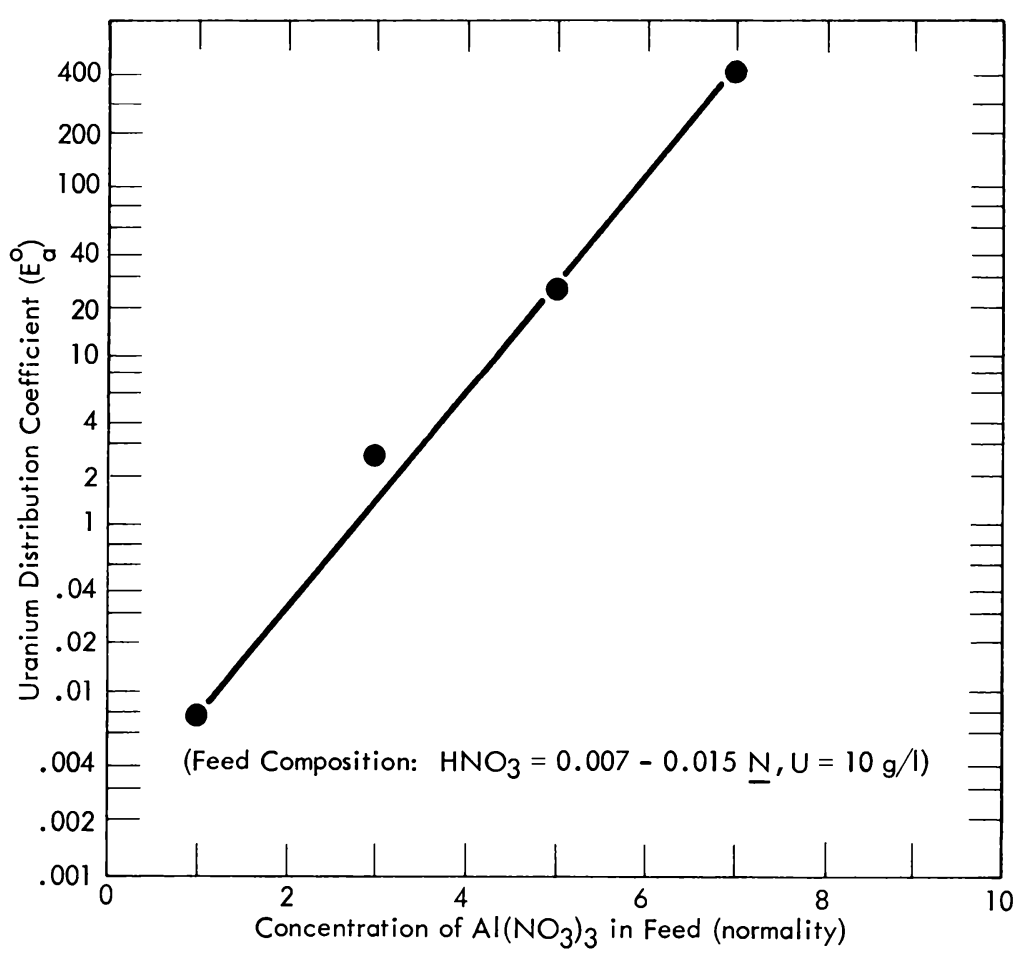

Figure 6. DISTRIBUTION OF URANIUM BETWEEN 1,5-DIMETHOXYPENTANE AND ALUMINUM NITRATE SOLUTION. 


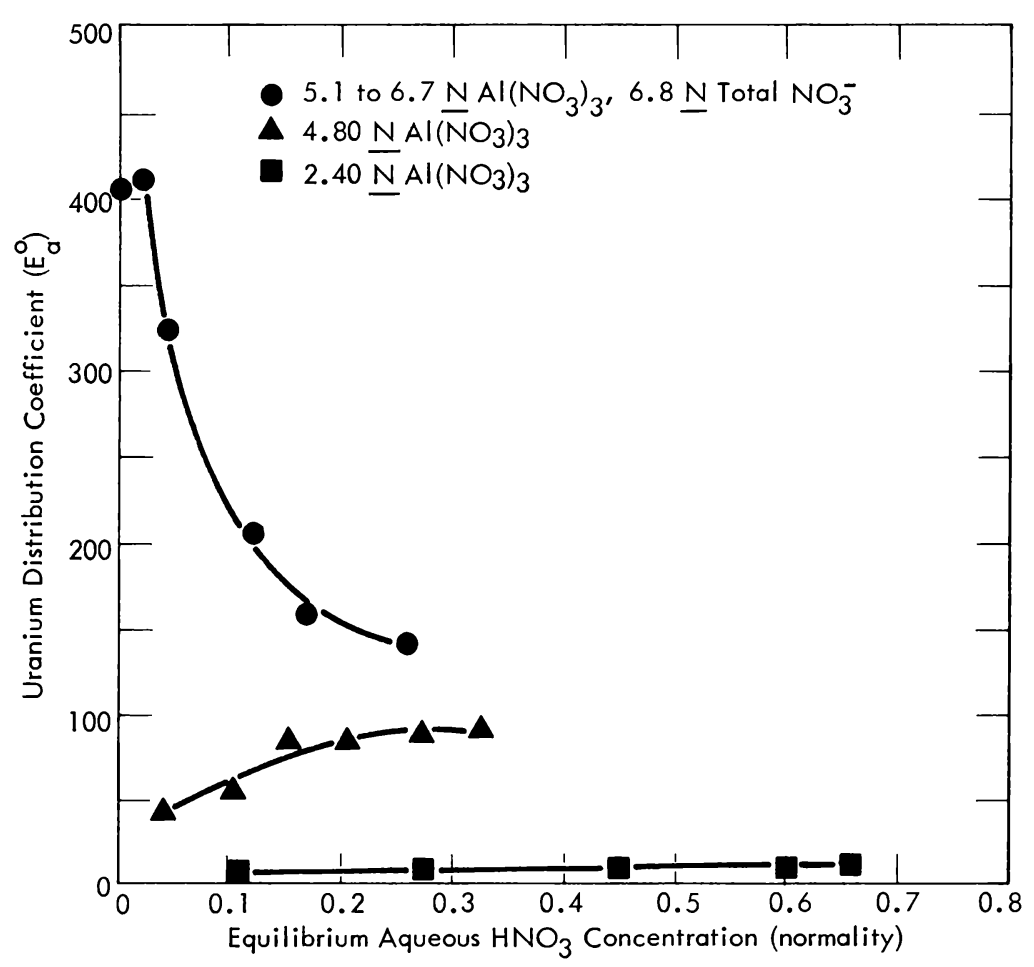

Figure 7. EFFECT OF NITRIC ACID ON THE URANIUM DISTRIBUTION COEFFICIENT BETWEEN 1,5-DIMETHOXYPENTANE AND AQUeOUS ALUMINUM NITRATE. (At Different Nitrate Concentrations $10 \mathrm{~g} \mathrm{U} / \mathrm{l}$ of feed)

salt concentration. The decrease in the distribution coefficient would not be so rapid if the salt normality were constant; however, it is apparent that a sharp decrease in the distribution coefficient would be expected at high salt concentrations with the addition of nitric acid. Accordingly, at high salt concentrations, the maximum extraction is obtained at very low aqueous acid concentrations.

With the $4.80 \mathrm{~N}$ nitrate solution, the distribution coefficient rises gradually with increasing acidity, leveling off at about $0.35 \mathrm{~N}$ acid. A very gradual rise is seen with the $2.40 \mathrm{~N}$ nitrate solution, although the distribution coefficients were low over the entire range of acid concentrations investigated.

The results of this series of tests agree with those previously reported for dibutyl Carbitol; (10) namely, that when nitric acid is added to a low-nitrate solution, the influence of the increased nitrate concentration on the uranium distribution coefficient is greater than those of the added hydrogen ion.

Effect of Nitric Acid on the Uranium Distribution Coefficient at a Constant Nitrate Ion Concentration

Extractions were performed with a series of feed solutions of varying acid concentration and a constant nitrate ion concentration of $6.80 \mathrm{~N}$. Prior to each extraction enough nitric acid was added to the 1,5-dimethoxypentane to approach the equilibrium acid concentration in the organic phase (based on the data in Figure 5) in 
order to minimize the extraction of the acid during the shakeouts. Thus, the nitrate concentration in the aqueous phase remained relatively constant. The results of these experiments are plotted in Figure 8. The curve for $6.8 \mathrm{~N}$ total nitrate from Figure 7 is reproduced in Figure 8. Comparison of the two curves shows that the distribution coefficients were somewhat higher with prior acidification of the organic than were obtained with no prior addition of acid to the organic phase. A rapid decrease in the distribution coefficient with increasing nitric acid concentration was again observed.

The best uranium extraction took place in the presence of the least amount of acid. A distribution coefficient of 486 was obtained with a $0.006 \mathrm{~N}$ acid concentration in the raffinate. This decreased to 124 at a raffinate acidity of $0.46 \mathrm{~N}$. These data indicate that extraction should be carried out at an acidity just high enough to prevent precipitation from the aqueous solution and to allow rapid phase separation.

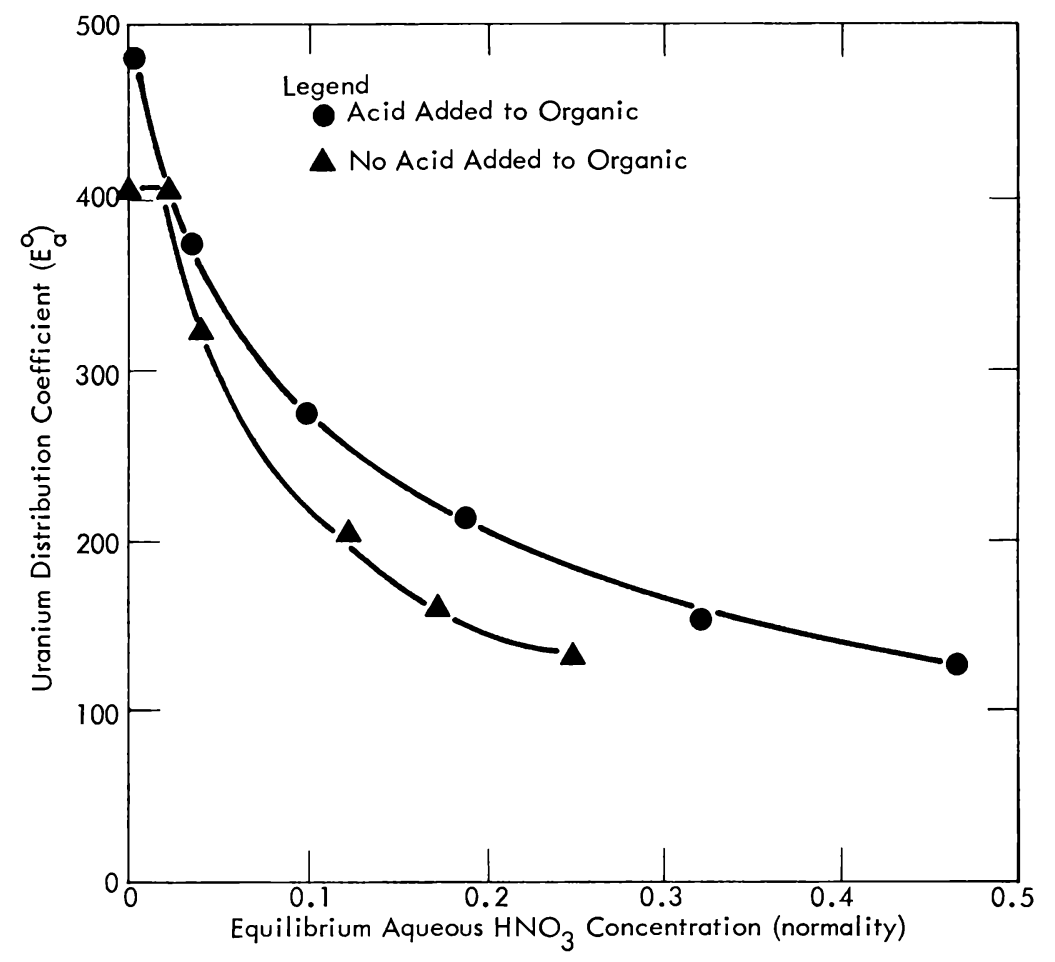

Figure 8. EFFECT OF NITRIC ACID ON THE URANIUM DISTRIBUTION BETWEEN 1,5-DIMETHOXYPENTANE AND AQUEOUS ALUMINUM NITRATE. (At a Constant Nitrate Concentration of 6.80 N and a Uranium Feed Concentration of $10 \mathrm{~g} /$ )

Distribution of Uranium Between Nitric Acid and 1,5-Dimethoxypentane

In order to determine the effect of nitric acid on the efficiency of uranium stripping, a series of uranium-loaded ether samples (containing 6.5 to $9.0 \mathrm{~g} \mathrm{U} /$ liter and with varying acid concentration) were extracted with equal volumes of distilled water. The uranium distribution coefficients (aq org) are plotted against the equilibrium aqueous acid concentration as given in Figure 9. The distribution coefficient dimin- 


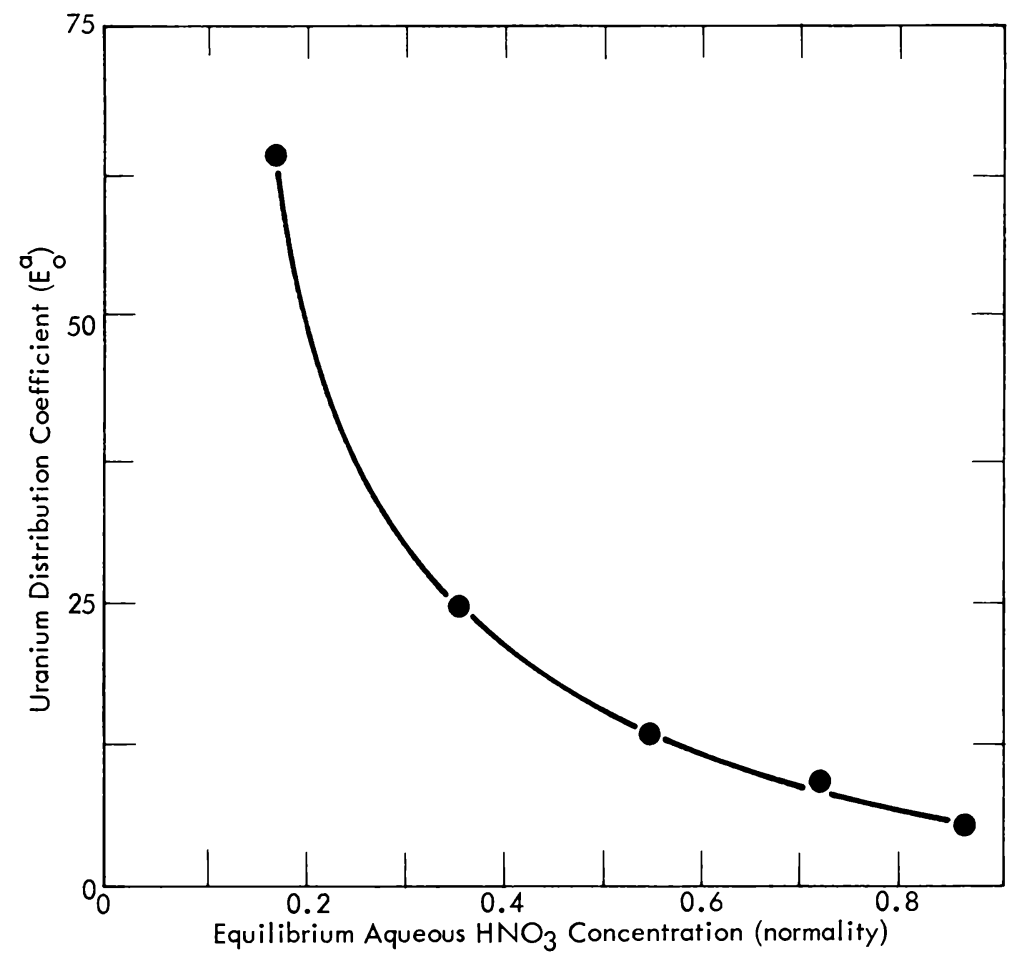

Figure 9. DISTRIBUTION OF URANIUM BETWEEN NITRIC ACID AND 1,5-DIMETHOXYPENTANE.

ishes rapidly as the acid concentration is increased to about $0.5 \mathrm{~N}$, beyond which the rate of decrease becomes more gradual. It may be concluded from Figures 8 and 9 that acid is undesirable during uranium stripping as well as during extraction. Uranium Capacity

A very important property of any extraction agent is its capacity, per unit volume, for the material being extracted. This characteristic was determined for the 1,5dimethoxypentane at an arbitrarily chosen set of conditions which favored a high distribution coefficient but which were not necessarily those for optimum operation of a column extraction system. The uranium loading was determined by a six-hour extraction of a feed solution which contained an excess of uranium. Results of the experiment are presented in Table 2. The loading at the given conditions was 0.3236 $\mathrm{g} \mathrm{U} / \mathrm{ml}$.

\section{Uranium Extraction Experiments With the Other Ethers}

A limited number of extraction experiments, similar to those described earlier, were performed with 1,5-diethoxypentane, 1-methoxy-5-ethoxypentane, hexy ethyl Carbitol, and dibutyl Carbitol. The extractions were performed under two sets of conditions chosen primarily to show the effect of salt concentration. These results are presented in Figures 10 and 11 . Extraction data for 1,5-dimethoxypentane, taken under similar experimental conditions, are included for purposes of comparison. 
Table 2

URANIUM CAPACITY OF 1,5-DIMETHOXYPENTANE

(Extraction Time - 6 Hours)

\begin{tabular}{lcccccc}
\hline \multicolumn{1}{c}{ Phase } & $\begin{array}{c}\text { Volume } \\
(\mathrm{ml})\end{array}$ & $\begin{array}{c}\text { Specific } \\
\text { Gravity }\end{array}$ & $\begin{array}{c}\text { Normality } \\
\mathrm{Al}\left(\mathrm{NO}_{3}\right)_{3}\end{array}$ & $\begin{array}{c}\text { Normality } \\
\mathrm{HNO}_{3}\end{array}$ & $\begin{array}{c}\text { Uranium } \\
(\mathrm{mg} / \mathrm{ml})\end{array}$ & $\begin{array}{c}\text { Distribution } \\
\text { Coefficient } \\
\mathrm{E}_{\mathrm{a}}^{\circ}\end{array}$ \\
\hline $\begin{array}{l}\text { Feed } \\
\begin{array}{l}\text { P-Dimethoxypentane (fresh) } \\
\text { Raffinate }\end{array}\end{array}$ & $\begin{array}{l}100 \\
\text { Extract }\end{array}$ & 1.4172 & 5.96 & 0.011 & 99.7 \\
\hline
\end{tabular}

The data in both figures are in accordance with predictions based on structural considerations in that the dimethoxy ether is the best extractant of the three dialkoxypentanes, the diethoxy the poorest, and the mixed ether intermediate between the two symmetrical ones.

The data obtained for the Carbitols is anomalous indicating that the two Carbitols have about the same extraction power at high salt concentrations, whereas the dibutyl Carbitol appears to be the superior extractant at lower nitrate strengths; and other data shows the hexyl ethyl Carbitol to be the superior extractant in accordance with its larger dipole moment.

A decrease in the salt concentration has a more damaging effect on the extraction power of the dialkoxypentanes than on the Carbitols.

Phase Separation Time

Another variable having considerable influence on the feasibility of using a given solvent as an extraction agent is the ease of separation of the phases. Table $3 \mathrm{com}-$ pares the separation times for the five ethers studied. The data indicate that a greater degree of acidity is necessary for rapid phase separation with the pentanediol ethers than with the Carbitols; however, the separation appeared to be more complete with the dialkoxypentanes than with the Carbitols. The latter remained cloudy after separation, while the former were very clear.

Extractability of Impurities

Evaluation of any solvent for uranium extraction would be incomplete without a consideration of its extraction capacity for those impurities from which the uranium must be separated. A feed solution was spiked with known amounts of nineteen different salts, chosen arbitrarily with some consideration being given to the spectrographic limits used by the Plant analytical laboratory. The extractions were performed in the manner previously described; the phases were separated and analyzed for uranium and the various added impurities. All elements except uranium, nickel, 


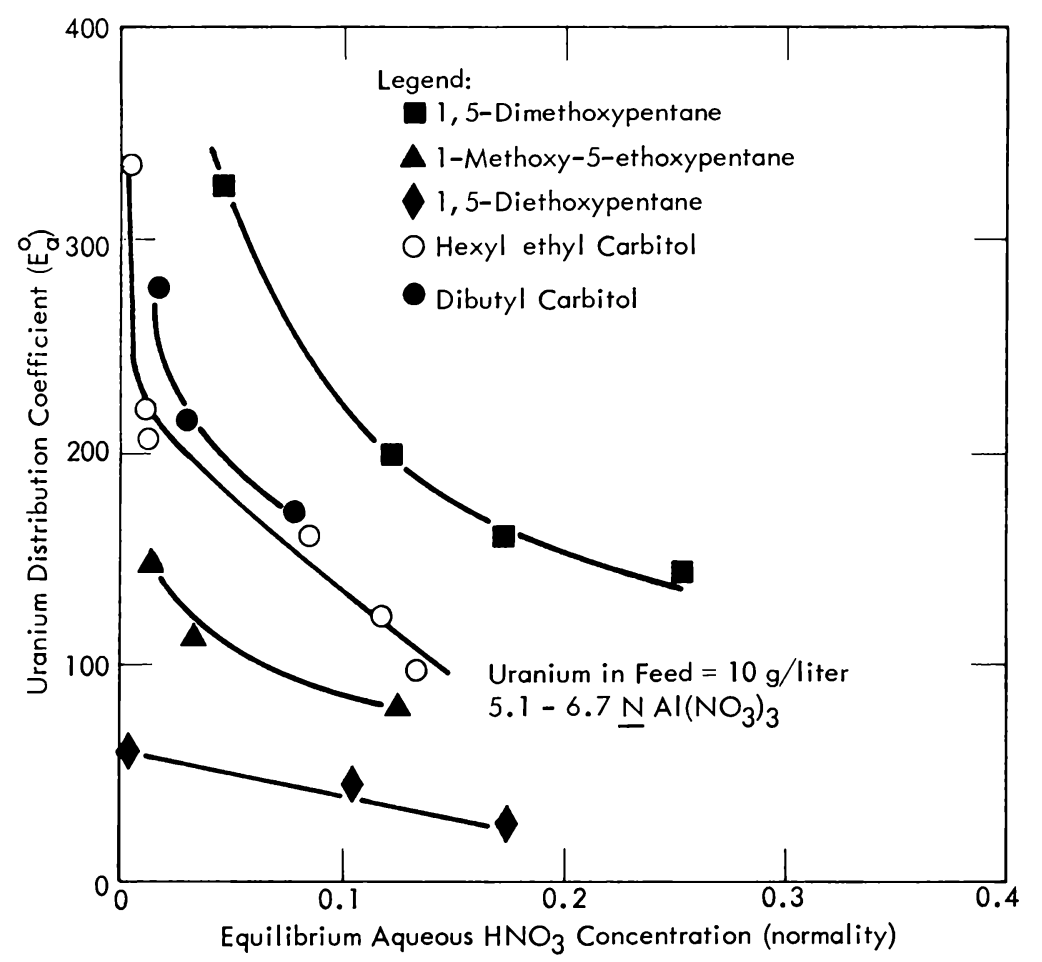

Figure 10. COMPARISON OF THE URANIUM DISTRIBUTION COEF. FICIENTS WITH INCREASING $\mathrm{HNO}_{3}$ CONCENTRATIONS. (At a Constant Nitrate lon Concentration of 6.8 N)

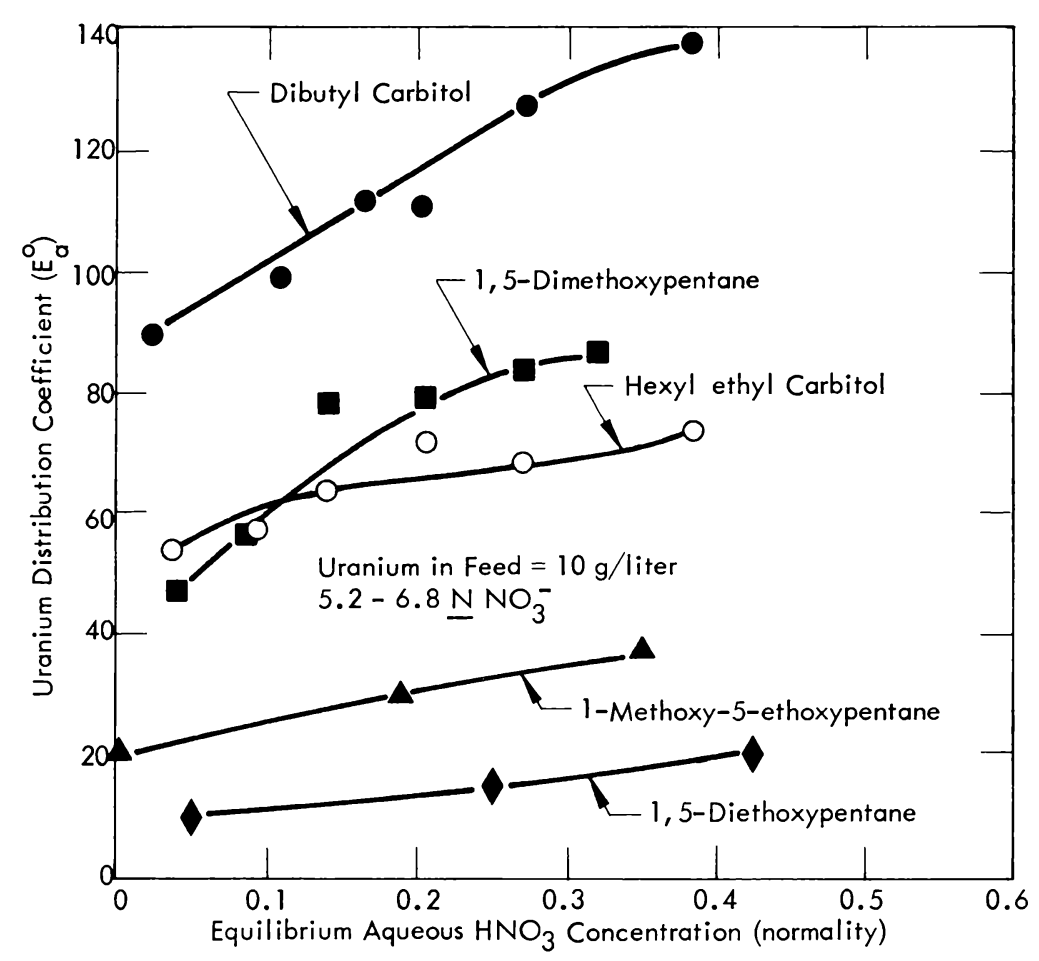

Figure 11. COMPARISON OF THE URANIUM DISTRIBUTION COEF. FICIENTS WITH INCREASING $\mathrm{HNO}_{3}$ CONCENTRATION. (At a Constant $\mathrm{Al}\left(\mathrm{NO}_{3}\right)_{3}$ Concentration of $4.80 \mathrm{~N}$ ) 
Table 3

PHASE SEPARATION TIMES FOR THE ETHERS

\begin{tabular}{|c|c|c|c|c|c|c|}
\hline & & \multicolumn{5}{|c|}{ Separation Time (min) } \\
\hline \multicolumn{2}{|c|}{ Feed } & \multirow[b]{2}{*}{ Dimethoxy } & \multirow[b]{2}{*}{ Diethoxy } & \multirow[b]{2}{*}{ Methoxy-Ethoxy } & \multirow[b]{2}{*}{ Dibutyl Carbitol } & \multirow{2}{*}{$\begin{array}{c}\text { Hexyl Ethy } \\
\text { Carbitol }\end{array}$} \\
\hline $\mathrm{HNO}_{3}(\underline{\mathrm{N}})$ & $\mathrm{Al}\left(\mathrm{NO}_{3}\right)_{3} \underline{\mathrm{N}}$ & & & & & \\
\hline 0.008 & 6.69 & 14.2 & -. & -- & 1.3 & 2.2 \\
\hline 0.274 & 6.39 & 2.6 & 0.8 & 2.3 & 0.7 & 1.2 \\
\hline 0.661 & 6.09 & 0.9 & 0.7 & 1.0 & 0.8 & 1.2 \\
\hline 0.841 & 5.76 & 0.4 & 0.8 & 0.8 & 0.9 & 1.2 \\
\hline 1.20 & 5.46 & 0.4 & -. & -- & 0.8 & 1.3 \\
\hline 1.44 & 5.13 & 0.5 & -- & -. & 0.6 & 1.3 \\
\hline 0.23 & 4.80 & 2.1 & -- & 2.0 & 0.6 & 0.8 \\
\hline 0.53 & 4.80 & 0.4 & -. & -- & 0.6 & 0.9 \\
\hline 0.84 & 4.80 & 0.3 & -. & 0.6 & 0.6 & 0.9 \\
\hline 1.08 & 4.80 & 0.3 & -- & -- & 0.7 & 0.9 \\
\hline 1.39 & 4.80 & 0.4 & -- & 0.5 & 0.7 & 1.0 \\
\hline 1.73 & 4.80 & 0.4 & -. & -- & 0.8 & 1.0 \\
\hline 0.23 & 2.40 & 2.2 & 0.4 & -- & 0.7 & 0.6 \\
\hline 1.49 & 2.40 & 0.6 & -- & 0.6 & 0.5 & 0.8 \\
\hline
\end{tabular}

iron, and chromium were measured by spectrographic analysis; these four were determined by spectrophotometric or potentiometric methods. Results of these extractions, showing the separation factors for the several impurities in four ethers, are presented in Table 4.

The low distribution coefficients for the various metallic impurities in the table indicate that a high degree of purification of the uranium is accomplished with each of the ethers. Variations in the uranium distribution coefficients in different ethers cause considerable differences in the separation factors, suggesting that the ethers with the higher uranium distribution coefficients are also superior in uranium purification. It had been expected that the better uranium extractants would also be better metal extractants, which would tend to equalize the separation factors in different ethers. This does not appear to be the case, although the accuracy of the distribution coefficients of most of the elements is limited by the semiquantitative nature of the spectrochemical analyses from which they were determined.

\section{Extraction of Zirconium}

Zirconium is one of the major impurities encountered in the $\mathrm{Y}-12$ uranium recovery systems, so its behavior toward any potential uranium extraction agent is of special interest. Extractions were made, using techniques similar to those described earlier, with 1,5-dimethoxypentane and dibutyl Carbitol and three different feed solutions in which the uranium-zirconium molar ratio was varied while maintaining a constant fluoride-to-zirconium ratio of 5 . For comparison purposes, a similar extraction was 
Table 4

EXTRACTION OF IMPURITIES IN AN Al $\left(\mathrm{NO}_{3}\right)_{3}$ SYSTEM (Spiked Feed Solution)

\begin{tabular}{|c|c|c|c|c|c|c|c|c|c|c|c|c|c|c|c|c|}
\hline \multicolumn{5}{|c|}{$\begin{array}{l}\text { Concentration in the Ether } \\
\qquad\left(\mu_{g} / \mathrm{ml}\right)\end{array}$} & \multicolumn{4}{|c|}{$\begin{array}{l}\text { Concentration in the Raffinate }{ }^{(1)} \\
\left(\mu_{g} / \mathrm{ml}\right)\end{array}$} & \multicolumn{4}{|c|}{ Distribution Coefficient $E_{a}^{\circ}$} & \multicolumn{4}{|c|}{ Separation Factor ${ }^{(2)}$} \\
\hline Element & $\begin{array}{l}\text { Dibutyl } \\
\text { Carbitol }\end{array}$ & $\begin{array}{l}\text { Hexyl Ethyl } \\
\text { Carbitol }\end{array}$ & 1,5-Dimethoxypentane & 1,5-Diethoxypentane & $\begin{array}{l}\text { Dibutyl } \\
\text { Corbitol }\end{array}$ & $\begin{array}{l}\text { Hexyl Ethyl } \\
\text { Carbitol }\end{array}$ & 1,5-Dimethoxypentane & 1,5-Diethoxypentane & $\begin{array}{l}\text { Dibutyl } \\
\text { Carbitol }\end{array}$ & $\begin{array}{l}\text { Hexyl Ethyl } \\
\text { Carbitol }\end{array}$ & 1,5-Dimethoxypentane & 1,5-Diethoxypentane & $\begin{array}{l}\text { Dibutyl 1 } \\
\text { Carbitol }\end{array}$ & $\begin{array}{l}\text { Hexyl Ethyl } \\
\text { Carbitol }\end{array}$ & 1,5-Dimethoxypentane & 1,5-Diethoxypentane \\
\hline $\mathrm{Ag}_{\mathrm{g}}$ & 0.25 & $<0.2$ & $<0.17$ & $<0.2$ & 28.7 & 28.8 & 28.8 & 28.8 & 0.0087 & $<0.0070$ & $<0.0060$ & $<0.0070$ & 120 & $>300$ & $>520$ & $>70$ \\
\hline $\mathrm{Al}$ & 4 & 10 & 6 & 4 & 17,496 & 17,490 & 17,494 & 17,496 & 0.0002 & 0.0006 & 0.0003 & 0.0002 & 5000 & 3000 & 10,000 & 2300 \\
\hline B & 0.3 & 0.15 & 0.6 & 0.1 & & & & 9.9 & 0.0300 & 0.0150 & 0.0640 & 0.0100 & 30 & 120 & 50 & 50 \\
\hline Bo & $<2.5$ & $<2.5$ & $<1.7$ & $<2.5$ & 998 & 998 & 998 & 998 & $<0.0025$ & $<0.0025$ & $<0.0017$ & $<0.0025$ & $>400$ & $>730$ & $>1,800$ & $>20$ \\
\hline $\mathrm{Bi}$ & 4 & 125 & -. & 5 & 736 & 615 & -- & 735 & 0.0050 & 0.2030 & -. & 0.0070 & 200 & 10 & -. & 70 \\
\hline $\mathrm{Ca}$ & $<12.5$ & $<12$ & $<8.3$ & $<12$ & 587 & 588 & 592 & 588 & $<0.0213$ & $<0.0200$ & $<0.0140$ & $<0.0200$ & $>47$ & $>90$ & $>2,200$ & \\
\hline $\mathrm{Cd}$ & $<0.1$ & $<0.1$ & $<0.1$ & $<0.1$ & 14.9 & 14.9 & 14.9 & 14.9 & $<0.0070$ & $<0.0070$ & $<0.0070$ & $<0.0070$ & $>200$ & $>300$ & & $>70$ \\
\hline co & $<1$ & $<1$ & $<1$ & $<1$ & 149 & 149 & 149 & 149 & $<0.0070$ & $<0.0070$ & $<0.0070$ & $<0.0070$ & $>200$ & $>300$ & & $>70$ \\
\hline$c r^{(3)}$ & $<1$ & $<1$ & $<1$ & $<1$ & 202 & 217 & 206 & 211 & $<0.0050$ & $<0.0046$ & $<0.0049$ & $<0.0047$ & $>200$ & $>390$ & $>630$ & $>95$ \\
\hline $\mathrm{Cu}_{\mathrm{H}}$ & $<0.5$ & $<0.5$ & $<0.3$ & $<0.5$ & 40 & 40 & 41 & 39.5 & $<0.0100$ & $<0.0100$ & $<0.0070$ & $<0.0100$ & $>80$ & $>100$ & & $>40$ \\
\hline $\mathrm{Fe}^{(3)}$ & $<2$ & 3 & $<2$ & $<1$. & 560 & 550 & 545 & 555 & $<0.0040$ & 0.0060 & $<0.0030$ & $<0.0020$ & $>300$ & 300 & $>1,000$ & $>30$ \\
\hline La & $<0.5$ & $<1$ & $<0.8$ & $<1$ & 1.7 & 1.2 & 1.4 & 1.2 & $<0.3000$ & $<0.8000$ & $<0.6000$ & $<0.8000$ & & $>2$ & & $>0.6$ \\
\hline & & & & $<0.1$ & 7.8 & 7.9 & 7.8 & 7.9 & $<0.0300$ & $<0.0100$ & $<0.0300$ & $<0.0100$ & $>40$ & $>100$ & & \\
\hline $\mathrm{Mg}$ & $<1.2$ & $<1$ & $<0.8$ & $<1$ & 159 & 159 & 159 & 159 & $<0.0075$ & $<0.0060$ & $<0.0050$ & $<0.0060$ & $>140$ & $>300$ & & \\
\hline $\mathrm{No}_{0}$ & $<2.5$ & $<1$ & $<1.7$ & $<1$ & 7.4 & 8.9 & 8.2 & 8.9 & $<0.3400$ & $<0.0100$ & $<0.2100$ & $<0.0100$ & $>3$ & $>200$ & & $>50$ \\
\hline $\mathrm{Ni}^{(3)}$ & $<1$ & $<1$ & $<1$ & $<1$ & 5240 & 5476 & 5240 & 5273 & $<0.0002$ & $<0.0002$ & $<0.0002$ & $<0.0002$ & 5000 & $>9000$ & $>20,000$ & $>2300$ \\
\hline $\mathrm{Pb}$ & $<1$ & $<1$ & $<1$ & $<1$ & 13 & 13 & 13 & 13 & $<0.0800$ & $<0.0800$ & $<0.0800$ & $<0.0800$ & $>10$ & $>20$ & & \\
\hline Sr. & $<20$ & $<20$ & $<20$ & $<20$ & 180 & 180 & 180 & 180 & $<0.1100$ & $<0.1100$ & $<0.1100$ & $<0.1100$ & & $>20$ & & \\
\hline$U^{(3)}$ & 5094 & 6520 & 8711 & 3190 & 5075 & 3586 & 2843 & 7042 & 1.0040 & 1.8180 & 3.0640 & 0.4530 & .. & - & .- &. \\
\hline
\end{tabular}

Foed: $10,000 \mu \mathrm{gU} / \mathrm{ml}, 0.49 \mathrm{~N} \mathrm{HNO}_{3}, 3.16 \mathrm{~N} \mathrm{NO}_{3}$.

(2) Separation Factor $=\frac{\text { Distribution Coefficient for Uranium }}{\text { Distribution Coefficient for Element }}$.

(3) Analyzed by spectrophotometric or potentiometric methods. 
made with 1,5-diethoxypentane. Results, summarized in Table 5, indicate excellent purification of uranium from zirconium by each of the three ethers.

Table 5

SEFARATION OF URANIUM AND ZIRCONIUM WITH DIBUTYL CARBITOL, 1,5-DIMETHOXYPENTANE, AND 1,5-DIETHOXYPENTANE

\begin{tabular}{|c|c|c|c|c|c|c|}
\hline \multicolumn{3}{|c|}{ Feed Solution ${ }^{(1)}$} & & \multirow{3}{*}{$\begin{array}{l}E_{a}^{\circ} \\
(U)\end{array}$} & \multirow{3}{*}{$\begin{array}{c}E_{a}^{\circ} \\
\left(Z_{r}\right)\end{array}$} & \multirow{3}{*}{$\begin{array}{c}\text { Separation Factor } \\
\qquad\left(\frac{U}{Z_{r}}\right)\end{array}$} \\
\hline & & Molar Ratio & & & & \\
\hline $\mathrm{mg} \mathrm{U} / \mathrm{ml}$ & $\mathrm{mg} \mathrm{Zr} / \mathrm{ml}$ & $U / Z r / F$ & Extractant & & & \\
\hline 10.060 & 3.83 & $1: 1: 5$ & Dibutyl Carbitol & 22.6 & 0.009 & 2511 \\
\hline 10.060 & 3.83 & $1: 1: 5$ & Dimethoxypentane & 34.1 & 0.021 & 1624 \\
\hline 9.898 & 1.90 & $2: 1: 5$ & Dibutyl Carbitol & 20.7 & $<0.004$ & $>5175$ \\
\hline 9.898 & 1.90 & $2: 1: 5$ & Dimethoxypentane & 31.1 & $<0.005$ & $>6220$ \\
\hline 5.037 & 3.83 & $0.5: 1: 5$ & Dibutyl Carbitol & 16.2 & 0.007 & 2385 \\
\hline 5.037 & 3.83 & $0.5: 1: 5$ & Dimethoxypentane & 26.3 & 0.009 & 2900 \\
\hline 9.965 & 3.83 & $1: 1: 5$ & Diethoxypentane & 13.1 & $<0.003$ & $>4370$ \\
\hline
\end{tabular}

(1) Feed also contained $0.3 \mathrm{~N} \mathrm{HNO}, 5.1 \mathrm{~N} \mathrm{Al}\left(\mathrm{NO}_{3}\right)_{3}$.

Separation of Uranium and Thorium

Some preliminary experiments were made to compare 1,5-dimethoxypentane and dibutyl Carbitol in their abilities to separate uranium and thorium. Three uraniumthorium feed solutions were prepared and extracted with each solvent. The conditions and results of the experiments are given in Table 6 . Since material balances for both uranium and thorium ranged from about 80 to about $120 \%$, the extraction coefficients and separation factors are only approximate. It appears that neither the uranium or thorium concentration has any marked effect on the thorium distribution coefficient, whereas at least one of these factors affects the uranium extraction.

It can be seen that the 1,5-dimethoxypentane is the better extractant of both uranium and thorium, but the Carbitol gives the better separation.

Solubility of the Ethers in Aqueous Solution

Pilot-plant studies (11) have indicated that the 1,5-dimethoxypentane, while showing a favorable uranium distribution coefficient, is too soluble in water for profitable use as a uranium extractant in continuous column extractions. Laboratory experiments have confirmed this.

The solubility of 1,5-dimethoxypentane in water was determined by contacting the ether with an equivalent volume of water. Each phase was weighed before and after equilibration, and the solubility of the ether was calculated by dividing the change in weight of the ether phase (after drying) by the final weight of the aqueous phase. The solubility of 1,5-dimethoxypentane in water was found to be $7.2 \%$ by weight, whereas that of 1,5-diethoxypentane was only 1.7\%. Although the diethoxy com- 
Table 6

SEPARATION OF URANIUM AND THORIUM

WITH 1,5-DIMETHOXYPENTANE AND DIBUTYL CARBITOL

\begin{tabular}{|c|c|c|c|c|c|}
\hline \multirow[b]{3}{*}{ Solvent } & \multicolumn{2}{|c|}{ Feed ${ }^{(1)}$} & & & \multirow[b]{3}{*}{ Separation Factor ${ }^{(2)}$} \\
\hline & \multirow{2}{*}{$\begin{array}{l}\text { Uranium } \\
\text { (mg/ml) }\end{array}$} & \multirow{2}{*}{$\begin{array}{l}\text { Thorium } \\
(\mathrm{mg} / \mathrm{ml})\end{array}$} & \multicolumn{2}{|c|}{ Distribution Coefficient $\left(E_{a}^{\circ}\right)$} & \\
\hline & & & Uranium & Thorium & \\
\hline \multirow[t]{3}{*}{ 1,5-Dimethoxypentane } & 10.90 & 1.030 & 230 & 5.5 & 42 \\
\hline & 4.968 & 4.850 & 130 & 5.5 & 24 \\
\hline & 0.999 & 9.040 & 29 & 5.3 & 5.5 \\
\hline \multirow[t]{3}{*}{ Dibutyl Carbitol } & 10.90 & 1.030 & 170 & 1.5 & 110 \\
\hline & 4.968 & 4.850 & 110 & 1.6 & 69 \\
\hline & 0.999 & 9.040 & 34 & 1.6 & 21 \\
\hline
\end{tabular}

(1) Feed also contained $0.3 \underline{\mathrm{N}} \mathrm{HNO}_{3}, 6.4 \underline{\mathrm{N} \mathrm{Al}}\left(\mathrm{NO}_{3}\right)_{3}$.

(2) Separation factor $=\frac{\text { Uranium distribution coefficient }}{\text { Thorium distribution coefficient }}$.

pound does nothave as high a uranium distribution coefficient as the dimethoxy ether, its capacity for uranium is adequate for multistage extraction systems. Considering its low solubility in water, coupled with other advantages common to both, 1,5diethoxypentane should prove to be useful in continuous column extraction.

While no solubility studies of the mixed ether have been made, it can be safely assumed that its water solubility lies between those of the two symmetrical ethers. 


\section{CONCLUSIONS}

The following conclusions have been made:

1. A comparison of the molecular structure of several oxygen-containing organic compounds with their uranium distribution coefficients has indicated that the extraction power of such compounds is a function of both the carbon-to-oxygen atomic ratio and the dipole moment.

2. Diethers containing six to eight carbon atoms and having four to six methylene groups between the "ether oxygens" atoms have been shown to be good uranium extractants.

3. The physical properties of 1,5-dimethoxypentane, 1,5-diethoxypentane, and 1 -methoxy-5-ethoxypentane were found to be generally superior to those of dibutyl Carbitol, relative to continuous column extraction; however, the use of 1,5-dimethoxypentane is severely limited by its high solubility in aqueous solutions.

4. These alkoxypentanes can be prepared in good yield from tetrahydropyran using hydrobromic acid and the appropriate sodium alcoholate.

5. All three dialkoxypentanes have ample capacity for uranium in multistage extraction systems. 1,5-Dimethoxypentane has the highest uranium distribution coefficient and 1,5-diethoxypentane the lowest with the mixed ether as a mean between the two. This is as theory predicts.

6. The uranium distribution coefficients increase with increasing aqueous $\mathrm{Al}\left(\mathrm{NO}_{3}\right)_{3}$ concentration and decrease with increasing free-acid concentration. Acid also interferes with the stripping of uranium from the organic phase by water.

7. Adequate purification of the uranium is obtained by extraction with any of the alkoxypentanes.

8. A decrease in the $\mathrm{Al}\left(\mathrm{NO}_{3}\right)_{3}$ concentration has a more damaging effect on the extraction power of the dialkoxypentanes than on the Carbitols. 


\section{REFERENCES}

(1) Glueckauf, E., McKay, H. A. C., and Mathieson, A. R., "The Partition of $\mathrm{UO}_{2}\left(\mathrm{NO}_{3}\right)_{2}$ Between $\mathrm{H}_{2} \mathrm{O}$ and Organic Solvents", Trans Faraday Soc, 47, pp 437-49 (1951).

(2) Burger, L. L., Dialkyl Diethers as Solvents-Structure Effects and the Extraction of Actinides. HW-7274l, Hanford Laboratories Operation, General Electric Company, Richland, Washington, February 2, 1962.

(3) Allen, J. S. and Hibbert, H., "Studies on Reactions Relating to Carbohydrates and Polysacchrides. XLVII. The Oxygen Valence Angle and the Structure of Glucose and Related Compounds", J Am Chem Soc, 56, p 1398 (1934).

(4) Williams, J.W., "The Dielectric Constants of Binary Mixtures. X. The Electric Moments of Simple Derivative of Cyclohexane and Dioxan". J Am Chem Soc,

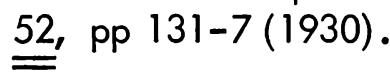

(5) Branch, G. E. K. and Calvin, M., The Theory of Organic Chemistry, p 143, Prentice-Hall, Inc, New York (1941).

(6) Brancia, Marko, "Cyclic Ether Extraction", Yugoslav-Polish Conference on Extraction Problems in Nuclear Technology, pp 60-8, September 7-13, 1961.

(7) Swistak, Edward, "Action of Cation Exchanges on Some Diols", Compte Rendus, 240, pp 1544-5 (1955).

(8) Wilson, Christopher, L., "Reaction of Furan Compounds, Part II. Fission of the Tetrahydrofuran and Tetrahydropyran Rings", J Chem Soc, pp 48-51 (1945).

(9) Googin, J. M. and Sprague, T. P., The Extraction of Uranium from Sodium Nitrate Solutions With Dibutyl Carbitol, Y-331, p 4, Union Carbide Nuclear Company, Y-12 Plant, Oak Ridge, Tennessee, January 26, 1949.

(10) Googin, J. M. and Sprague, T. P., The Extraction of Small Amounts of Uranium from Magnesium Nitrate Solutions With Dibuty Carbitol, Y-327, p 12, Union Carbide Nuclear Company, Y-12 Plant, Oak Ridge, Tennessee, January 20, 1949.

(11) Hamrin, C. E. Private Communication, Union Carbide Nuclear Company, Y-12 Plant, Oak Ridge, Tennessee, December 1960.

(12) Weisburger, Arnold, (editor), Technique of Organic Chemistry, Vol I, pp 166-76, Publishers, Inc, New York (1945).

(13) Glasstone, Samuel, Textbook of Physical Chemistry, 2nd Edition, pp 548-9, D. Van Nostrand Company, Inc, New York (1946). 
APPENDIX 


\section{METHODS OF DETERMINING PHYSICAL PROPERTIES}

\section{SPECIFIC PROPERTY}

\section{Boiling Points}

The boiling points or boiling ranges of the various laboratory-prepared compounds were taken as the vapor temperatures of the fractions being removed from the fractional distillation apparatus. In the case of the commercial materials the data were taken from the literature.

\section{Viscosities}

The viscosity determinations were made in a small Ostwald Viscometer. The measurements were made in a water bath that was maintained at a temperature of $25 \pm 0.1^{\circ} \mathrm{C}$. The flow times (measured to the nearest 0.01 minute) were compared to those of $\mathrm{CO}_{2}$-free water in the same viscometer, and the viscosities of the organic liquids were calculated from the comparison.

Refractive Index

Refractive indices were determined directly at $25 \pm 0.1^{\circ} \mathrm{C}$ with a Abbe Refractometer (Bausch and Lomb Optical Company, Model 33-45-56).

Interfacial Tensions

The interfacial tensions between the solvents and water were determined at $25 \pm 0.1^{\circ} \mathrm{C}$ by the drop-weight method of Harkins. (12) The volume of water dropped into the water-saturated solvent was measured in a Mohr pipette attached to a capillary through a ground-glass joint. The volume per drop was determined and weight of the drop calculated. The interfacial tension was calculated from this value, the previously determined density of the solvent, and the measurement of the outside diameter of the capillary face.

Densities

Densities of the solvents were measured at $25 \pm 0.1^{\circ} \mathrm{C}$ either in a calibrated 500microliter pipette or in a calibrated 10-milliliter specific gravity bottle with a thermometer attachment, depending on how much liquid was available.

Distribution Coefficients

Uranium distribution coefficients shown in Table 1 were determined with two standard solutions: 
1. $\mathrm{UO}_{3}+\mathrm{HNO}_{3}+\mathrm{H}_{2} \mathrm{O}(9.92 \mathrm{~g} \mathrm{U} / \mathrm{l} ; \mathrm{pH}$ after $1 / 25$ volumetric dilution was 2.00$)$. 2. $\mathrm{UO}_{3}+\mathrm{HNO}_{3}+\mathrm{NH}_{4} \mathrm{NO}_{3}+\mathrm{H}_{2} \mathrm{O}(9.74 \mathrm{~g} \mathrm{U} / \mathrm{l} ; \mathrm{pH}$ after $1 / 25$ volumetric dilution was 2.00; half saturated with $\mathrm{NH}_{4} \mathrm{NO}_{3}, \sim 515 \mathrm{~g} \mathrm{NH}_{4} \mathrm{NO}_{3} /$ liter).

Known volumes of the solvents were shaken with equal volumes of the feed solutions for two minutes and the amount of uranium in each phase was determined. The distribution coefficient, defined as:

Concentration of Uranium in the Organic Phase centrations.

Dipole Moments

The dipole moments of several of the solvents were determined at $25^{\circ} \mathrm{C}$ by the Dilute Solution Method(13) using an impedence bridge (General Radio Company 1650-A) for determining the dielectric constants, and benzene as the diluent. 
UNCLASSIFIED

UNCLASSIFIED 